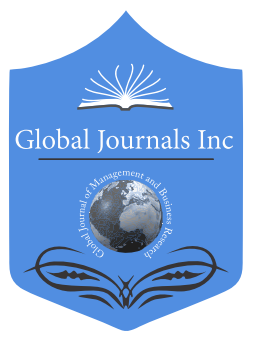

\title{
Financial Crises and Failed Corporate Governance
}

By William C. Handorf

George Washington University

Abstract- The banking sector is special given the importance of credit to support economic growth, and enormous public costs periodically sustained to bailout extensive institutional failures. US banks fail in waves approximately every generation and are unable to cope with severe economic downturns and incur excessive risk in a predictable and preventable manner. Is good corporate governance focusing on efforts to refresh boards by age or term limits the cause of episodic failure? As institutions refresh boards, banks lose directors with experience related to prior periods of crisis. Consistent with the availability heuristic, recall and memory are important to judgment. If relatively few directors have personal experience of a prior financial disaster, they are unable to recommend more conservative strategies. While some deservedly will believe the proposal a reversal in good governance, banks should consider suspending term and/or mandatory age limits for a few directors. Each board will need to overcome common "blind spots" that young equals good. Ageism is well-known and documented.

Keywords: g2 (financial institutions \& services) and g3 (corporate finance \& governance).

GJMBR-C Classification: JEL Code: G01

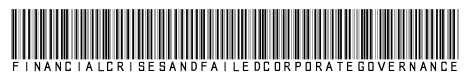

Strictly as per the compliance and regulations of:

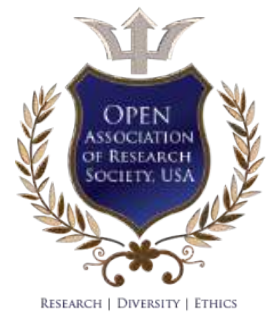

(c) 2019. William C. Handorf. This is a research/review paper, distributed under the terms of the Creative Commons AttributionNoncommercial 3.0 Unported License http://creativecommons.org/licenses/by-nc/3.0/), permitting all non-commercial use, distribution, and reproduction in any medium, provided the original work is properly cited. 


\title{
Financial Crises and Failed Corporate Governance
}

\author{
William C. Handorf
}

\begin{abstract}
The banking sector is special given the importance of credit to support economic growth, and enormous public costs periodically sustained to bailout extensive institutional failures. US banks fail in waves approximately every generation and are unable to cope with severe economic downturns and incur excessive risk in a predictable and preventable manner. Is good corporate governance focusing on efforts to refresh boards by age or term limits the cause of episodic failure? As institutions refresh boards, banks lose directors with experience related to prior periods of crisis. Consistent with the availability heuristic, recall and memory are important to judgment. If relatively few directors have personal experience of a prior financial disaster, they are unable to recommend more conservative strategies. While some deservedly will believe the proposal a reversal in good governance, banks should consider suspending term and/or mandatory age limits for a few directors. Each board will need to overcome common "blind spots" that young equals good. Ageism is well-known and documented. The proposal is consistent with academic research demonstrating that some attributes of "good governance" have proven harmful to firms in a crisis. There are problems for boards dominated by many longserving directors as identified by the CEO allegiance hypothesis. However, having no long-term, independent director experience has its own risk in the banking sector failure.
\end{abstract}

Keywords: g2 (financial institutions \& services) and g3 (corporate finance \& governance).

\section{InTRODUCTION}

W ith financial history as a guide, the US banking system is halfway between the Great Recession when almost 500 institutions failed and the next debacle. History need not repeat but does so with uncanny regularity. Why are bankers unable to learn from experience? The error learning model allocates failure to several categories to include preventable bankruptcies in predictable situations. ${ }^{1}$ Is good corporate governance contributing to these episodic managerial mistakes for the banking sector? The governance and financial crisis literature offer limited guidance. Most studies agree that the board of directors is the cornerstone of the governance framework. Failures leading to bankruptcy can be traced to directors failing to exercise their responsibilities, and an inability of the board to comprehend the complexity of their business. ${ }^{2}$ Academic and practitioner studies reach conflicting views of the composition and structure of the board leading to failure during crises. Many, but

Author: Ph.D, School of Business, Department of Finance, George Washington University, Washington. e-mail: whandorf@gwu.edu not all, studies suggest banks with more diverse independent directors adopt more conservative policies and achieve better credit ratings conducive to survival. Although banks have relied more fully on independent directors to provide advice and monitoring, failure has not abated during periods of economic and financial upheaval.

According to a recent survey compiled by Spencer Stuart, the average tenure of a Standard \& Poors 500 independent director in the US is 8.2 years and 82 percent of directors have been on their board less than 16 years. To refresh the board, 42 percent of firms mandate a maximum retirement age of $75^{3}$. As a result of forced and voluntary turnover, the average bank can be directed by three distinct boards between crises that occur approximately every 20 to 25 years. Each successive board invariably believes it is more capable than predecessors and risk management models better calibrated. Failure is considered remote and not an agenda item highlighted for discussion. "We are smarter" is a common refrain. Hubris remains constant as a character trait across generations of management and boards.

According to another survey by Institutional Shareholder Services (ISS), "Refreshment is among the most hotly-debated topics across US boardrooms and within the broader corporate governance community. Among institutional investors, 68 percent pointed to a high proportion of directors with long tenure as cause for concern. Some urge wider use of forced exit mechanisms, such as mandatory retirement ages or term limits." 4 Subramanian provides a counter-argument, "Boards have an obligation to ensure the proper mix of skills and perspectives. Age and term limits are a blunt instrument for achieving optimal board composition." We explore failure in the banking industry to determine if periodic crises and financial panics are predictable and preventable, and to assess what extent corporate governance contributes to the inability to learn from the long and costly experience.

We later recommend that banks suspend mandatory term or age limits for a few directors to ensure the board is better able to retrieve the lessons of prior crises. Award-winning work in the social psychology field by Tversky and Kahneman suggest that recall and memory are important to judgment. If an event is easier to recall or retrieve from memory, it can be applied more quickly and fully when developing 
strategy according to the availability heuristic. Theorists, practitioners and investors deservedly will find the modest proposal to suspend term or age limits for several directors within the banking sector as a major reversal in good corporate governance. However, banks are a special sector of commerce.

\section{Current State of the Industry}

The banking sector is different than other industries given the importance of access to credit by consumers and businesses to support economic growth. Massive public costs incurred by the Federal Deposit Insurance Corporation (FDIC), Federal Reserve System and Department of Treasury to resolve potentially hundreds of institutional failures add to the specialness of the financial sector. However, concern with the health of the banking system appears misplaced ten years after the last financial calamity. ${ }^{6}$

The US banking system is currently robust given consistent profits and sufficient capital to pay shareholders respectable dividends, repurchase stock and still retain adequate earnings to support growth and originate new loans critical to sustaining economic expansion.

Preliminary anecdotal evidence shows risks are creeping back into the financial system that invariably precede a crisis. Many analysts undoubtedly will apply Fishoff's hindsight bias heuristic and arrange emerging evidence into a more confident account of the antecedents of failure after the next wave of bank liquidations. ${ }^{7}$ There are very few projections of eminent financial disaster. Rizzi, however, reminds bankers of the risks, "You are assured of losing money if you are complacent and ignore the inherent cyclicality of banking, believing this time is different."

- The Office of the Comptroller of the Currency identified the easing of commercial loan standards as a top risk in the industry. The Comptroller warned, "The worst loans are often made in the best of times." 9

- The Economic Growth, Regulatory Relief and Consumer Protection Act of 2018 raised the threshold over several years for systemically important financial institutions to $\$ 250$ billion thereby reducing institutions subject to more restrictive regulation from 38 to $12 .{ }^{10}$

- Investors are increasingly relying on "drive-by" appraisals to value large pools of residential mortgage collateral. Such valuations are a quick and inexpensive method to value houses. Although Congress prohibited such valuations for traditional mortgages originated by banks following the last crisis, the restrictive rules do not apply to institutional investors. ${ }^{11}$
- After years of low interest rates consistent with an accommodative monetary policy engineered by the Federal Reserve, investors are seeking high-yield investments and aggressively purchasing leveraged-debt securities with far fewer protective covenants than common several years ago and expose creditors to higher losses given default in the next downturn. ${ }^{12}$

Despite the illustrative warnings and red flags, the public can take solace from another regulatory pronouncement the Comptroller of the Currency previously provided Congress, "Under the provisions of the new law, the failure of efficiently and honestly managed banks is practically impossible." ${ }^{13}$ The year quoted was1914 - not a century later - following the creation of the Federal Reserve System. Regulators, like bankers, also retain confidence the most recent financial disaster will be the last given safeguards of a new restrictive law passed by Congress and creation of a regulatory body to ensure the mandate is accomplished.

Bank crises are not a new phenomenon. A crisis can include a panic where the financial markets, the inter-bank market and depositors lose confidence in the banking sector and withdraw funds, and failure when many institutions are liquidated or merged by regulatory authority. Crises occur in the US and other countries approximately every generation.

Prior to more fully reviewing the financial, economic and managerial reasons banks fail, it is useful to briefly note the similarity of the occurrence and the resolution of bank failures and periodic market panics in the United States during the past century. Increasingly more advanced financial models incorporating more powerful technology, erudite mathematical algorithms, advanced financial logic and restrictive statistical assumptions, coupled with managerial confidence, lull bankers and regulatory supervisors alike into unwarranted confidence and complacency. Prudential corporate governance discourages retention of board members with long tenure and experience extending to the preceding crisis. The $20^{\text {th }}$ century American philosopher Santayana penned the oft-repeated phrase, "Those who cannot remember the past are condemned to repeat it." 14

\section{ili. Prior Banking Crises}

After winning the presidential election in 1912, Woodrow Wilson placed high priority on banking reform as a result of the devastating banking crisis and severe recession of 1907. The Federal Reserve Act of 1913 created the existing central bank. Commercial banks could now look to the Federal Reserve for a source of liquidity should nervous depositors withdraw funds given concerns about the safekeeping of a local or city bank. The formation of the central bank did not end bank 
failures or financial panics over the next century. Hummel, among many commentators, staunchly criticizes the Federal Reserve System, "There is more than a prima facie case against the Fed's success at either stabilizing the US economy or preventing banking crises." 15

The Banking Act of 1933 established the Federal Deposit Insurance Corporation and gave the new agency the authority to provide federal deposit insurance as of 1934 following numerous bank failures and bank runs resulting from the Great Depression, the Dust Bowl and subsequent National Banking Holiday when deposit institutions were closed to provide regulators time to differentiate viable from failing banks. Despite the creation of a momentous new federal regulatory agency protecting modest customer deposits, banks continued to fail and financial crises periodically persisted over the ensuing 80 years.

Researchers long have noted bank failures coincide with adverse developments in the economy. Freidman \& Swartz contend problems in the financial system worsen an economic contraction by reducing the wealth of bank shareholders and precipitating a rapid decline in the supply of money. ${ }^{16}$ Bernanke extends their pioneering work by evaluating how debtor bankruptcies may further affect economic output. He indicates, "As the real costs of intermediation increase, some borrowers (especially households, farmers and small firms) find credit to be expensive and difficult to obtain. The effects of this credit squeeze on aggregate demand helped convert the severe downturn of 1929-30 into a protracted depression."17 Any investigation of bank failure must recognize the impact of bank liquidations on the economy and simultaneously consider the loss of economic output on the ability of debtors to both obtain and repay bank loans.

The Federal Reserve shocked the markets in 1979 by dramatically increasing short-term interest rates to control inflation that then sharply exceeded policy goals. The action had unintended consequences for the soon-to-be beleaguered savings and loan or thrift industry. Thrifts provided long-term, fixed-rate mortgage loans to local home owners funded by short-term insured deposits subject to rate ceilings then imposed by regulation $Q$. S\&Ls suffered severe disintermediation as customers withdrew funds in favor of Treasury securities offering higher yields than financial institutions were then able to pay on deposit products. Congress passed several laws, to include the Depository Institution Deregulation and Monetary Control Act of 1980 and the Depository Institutions Act of 1982 to alleviate the industry's liquidity and interest rate risk difficulties by allowing thrifts to extend credit in areas they had no experience. The new lending authority turned out badly as problem loans proliferated, net interest margins narrowed or turned negative, and capital evaporated; about one-third of the 3,200 thrifts failed between 1986 and 1995.

The Financial Institutions Reform, Recovery and Enforcement Act of 1989 created the Resolution Trust Corporation to liquidate and manage insolvent thrifts, imposed new restrictions, abolished the supervisory authority of the Federal Home Loan Banks and created a new, and short-lived agency, called the Office of Thrift Supervision to oversee the rapidly shrinking industry. As a result of the turmoil, commercial banks aggressively entered the residential mortgage loan market vacated by thrift institutions thereby setting the stage for the next crisis. Despite the attention of public policy to the thrift industry, Boyd and Gertler lay blame to the nation's largest banks during this period and raised the profile of TBTF or too-big-to-fail featured in subsequent law following the next disaster. They indicate, "Large banks were mainly responsible for the unusually poor performance of the overall industry. First, deregulation and financial innovation led to increased overall competition for the banking industry. Second, the existing regulatory environment tended to subsidize risktaking by large banks more than small banks. The rationale was based on the Great Depression when the failure of a large bank could be contagious." 18

Rapidly rising home prices preceding the Great Recession encouraged prospective home owners, longterm investors and short-term flippers or speculators to purchase properties funded by high-risk loans and very high loan-to-value ratios. Banks and brokers originated high-yield loans and willingly extended subprime financing to individuals with impaired credit, accepted low-documentation loans with little verification of income and cash flow, and structured loans with payments initially set low and exposed unsuspecting mortgagors to subsequent payment shock. The loans were packaged and sold to Wall Street investment banks to create Private Label Mortgage Backed Securities, which were then cannibalized to create even more exotic and toxic Collateralized Mortgage Securities (CMO) promising even higher returns. The CMOs quickly lost substantial value when mortgagors with subprime credit and undocumented sources of cash flow were unable to cover payments that afterward increased in the most recent, but by no means the last, banking crisis.

Congress and the administration responded to the Panic of 2008 with policy initiatives comparable to that which has followed US banking crises over the past century: 1) conduct hearings, 2) enact new restrictive laws that attempt to prevent similar abuses in the future, and 3) create a new regulatory agency to promulgate rules and monitor institutional compliance with the law. The Wall Street Reform and Consumer Protection Act of 2010 created the Consumer Financial Protection Bureau, and required banks, especially those deemed to be systemically-important or TBTF, to increase 
funding by equity capital, direct more attention to maintaining adequate levels of liquidity and enhance risk management. Calomiris directs especial attention to misplaced policies of Congress that encouraged risktaking and partly holds legislators responsible for the almost 500 bank failures during and subsequent to the Great Recession. He indicates, "Numerous housing policies promoted subprime risk by subsidizing the inexpensive use of financial leverage. These policies included political pressures from Congress on Fannie Mae and Freddie Mac to promote 'affordable housing' by investing in high-risk, subprime mortgages and 2006 legislation enacted to encourage rating agencies to relax standards for subprime securitizations." ${ }^{19}$

The US has a long and undistinguished historical record of bank failure, market panic and legislative response. The cycle raises many questions. Why do well conceived public policy initiatives precipitate unintended consequences leading to subsequent bank failure? What issues exist, if any, beyond an adverse economy, deregulation, too-big-tofail incentives, flawed reliance on optimistic models, ignorance of risk, mis-priced and questionable acquisitions, and mismanagement? Are these preventable problems in predictable situations that should have been discovered and acted upon by knowledgeable and experienced bank directors? Parsons cites the results of almost 100 FDIC Material Loss Reviews that highlight issues leading to governmental losses incurred when banks are liquidated or merged, "Ineffective bank directors are identified as a primary cause of bank failure." 20

\section{BANK FAILURE}

Banks ultimately fail because of inadequate capital and/or a liquidity crisis. A few banks have been considered well-capitalized and liquid, yet were closed by regulatory authorities as a result of fraud or money laundering, such as existed at the Bank of Credit and Commerce International in 1991 or United American Bank and related institutions controlled by the Butcher brothers in Tennessee and Kentucky in 1983/4. These institutional problems are anomalies.

Capital ratios usually decline to very low or negative levels given excessive losses on high-risk loans and, more recently, highly-rated mortgage investment securities that quickly migrated to speculative status and/or default. The poorly underwritten troubled loans and securities are neither supported by adequate levels of loan loss reserves nor priced appropriately for risk. The problems are more pronounced when a bank retains a concentrated portfolio experiencing greater than expected losses. Kindleberger, among other academics, claim that bank failures are part of the business cycle and result from myopic foresight by bankers. ${ }^{21}$ Bank capital ratios also decline when undue growth is funded by high-cost, non-core uninsured and broker-placed deposits and borrowed money. Capital ratios decline as assets grow more quickly than equity capital. In addition, bank internal controls and underwriting ability prove inadequate to support periods of above-average growth. Management invariably react to excessive losses by shrinking the balance sheet to maintain fragile and deteriorating capital ratios. The shrinkage strategy merely exacerbates losses as fixed operating expenses become a progressively larger share of declining income.

Once a bank's capital, asset quality and earnings problems are well known by regulatory supervisors, credit rating agencies and the inter-bank market, liquidity issues arise. The press publishes adverse articles about the financial problems of the bank. Core and non-core depositors alike withdraw funds. If a rapidly deteriorating bank has little highquality collateral available for pledging at the central bank or correspondent banks, liquidity pressures deepen. Weak banks lacking unencumbered quality assets are unable to borrow funds in the inter-bank market even on a short-term basis. Diamond and Dybvig believe the mission of the banking industry is conducive to precipitating banking panics, "Banks create liquidity risk for themselves as they provide liquidity to customers in the form of loan commitments and mismatched terms of longer term assets funded by shorter term liabilities."22 Ultimately, banks fail because management and the board of directors are unable to establish a viable business plan implemented by qualified management, and unwilling or unable to identify, measure, monitor and control risks commensurate with a safe and sound institution.

High-risk residential and commercial mortgage loans and loans to high-risk mortgagors fueled the most recent US banking boom and bust. Prior crises have featured problematic loans to the energy, agriculture, commercial real estate and developing country sectors. Institutions invariably emulate early entrants initially enjoying high yields yet do not fully analyze the inherent risks. While asset classes precipitating panics and failure change over time, the preventable process leading to liquidation is remarkably similar. A former Comptroller of the Currency responsible for regulation and supervision of national banks indicated: "The [bank] failures for the current year have been numerous, many having been characterized by gross mismanagement and some by criminality of an aggravated nature...." Although these words easily could have been written in the US during or just after the Great Recession, they were penned in 1891. ${ }^{23}$ Bank crises fueled by mismanagement and, sometimes fraud, are a recurring chapter of American financial history over a very long period of time. The economic, financial and managerial issues precipitating failure are next evaluated from the 
devastating US banking experience during the Great Recession.

\section{Leading Causes of Failure During the Great Recession}

The Economy: Bank failure has long been linked to adverse conditions of the economy. There is disagreement and debate whether economic contractions precipitate conditions conducive to bank failure or whether bank problems cause or worsen economic recessions. We provide recent evidence of bank failure and related economic and market metrics indicative of prior business cycles to assess whether bank directors should have identified the deteriorating macro-economic environment prior to the recent crisis. Other researchers previously cited have exhaustively examined economic conditions and bank failure. Our empirical objective merely illustrates red flags a knowledgeable director should or could have identified prior to the Great Recession to guide adoption of more conservative financial strategies consistent with survival. Table 1 reviews 25 years of illustrative banking and economic data between 1992 and 2017. Was the most recent upsurge of bank failure preventable and easily observed by an alert and experienced board?

- On average, 32 banks failed annually in the US over the quarter century depicted and ranged between zero in both 2005 and 2006 to 180 in 1992 and 154 in 2010. Relatively new directors can be lulled to complacency when there are no headlines applicable to bank liquidation or panics.

- The average, annual real or inflation-adjusted gross domestic product (GDP) expanded by 2.54 percent per year over the 25 years illustrated and ranged from 4.69 percent in 1999 to -2.78 percent in 2009.

- The annual consumer unemployment rate averaged 5.97 percent and ranged between 4.00 percent in 2000 and 9.60 percent in 2010.

We employ statistical correlation analysis to study the influence between the economy and bank failure. Correlation analysis provides a measure of the relative, not absolute, relationship between variables and does not suggest causality or economic consequence. Table 2 illustrates the coincident and one-year lagged bank failure correlation data that can range from +1.00 or perfect positive correlation to 1.00 or perfect inverse correlation. Our analysis is focused on whether flawed governance led to failure rather than extensive econometric analysis of failure already cited.

- The correlation between real GDP and bank failure is negative as expected. When the economy is expanding, fewer banks fail and as fewer banks are liquidated the economy expands. The correlation coefficient is -.36 on a coincident basis, which is significant at the five percent level and -.74 on a one-year lagged basis, which is significant at the one percent level. The confidence level represents the likelihood of wrongly rejecting the null hypothesis indicative of no relationship between the variables tested. Based on the simplistic statistical results, economic conditions impact loan losses, earnings, capital and ultimately failure. And, bank failures deepen the economic malaise.

- The correlation between the unemployment rate and bank failure is positive as expected. As households lose the ability to generate cash flow from employment, they pay obligations more slowly, if at all. Banks incur more slow, non-accrual and classified loans and the resultant credit problems are only partly resolved by loan modification or foreclosure. The correlation coefficient between bank failure and unemployment is .83 on a coincident basis and .60 on a lagged basis; the statistical relationship is significant at the one percent level for either perspective.

The cursory analysis merely confirms that recessionary economic conditions and bank problems are strongly related. The rudimentary statistical analysis begs the question of how bankers, directors and regulators can assess deteriorating economic conditions prior to a recession. There are no perfect models but the yield curve slope and credit spread provide well known and valuable managerial estimates suggestive of an adverse economic environment detrimental to bank viability. Attentive and knowledgeable directors need to act on the information suggestive of economic weakness to modify business plans and reduce risk exposure before a contraction.

The yield curve slope reflects the difference in yield between long-term and short-term debt securities. The yield curve slope shown in Table 1 represents the difference in yield between 10-year US Treasury notes and three-month US Treasury bills. Over the period sampled, the slope averaged 1.91 percent and ranged between 3.58 percent in 1992 and .07 percent in 2006 . The US Treasury yield curve reflects expectations of future short-term interest rates and a liquidity premium investor's demand for accepting incremental price risk with long-term, high duration securities. ${ }^{24}$

An upward sloping yield curve, such as existed in 1992 or 2003, suggests interest rates will rise, which is consistent with a recovering or expanding economy. An inverted or flat yield curve, such as occurred in 2006, provides evidence interest rates will decline, which is compatible with a slowing or contracting economy.

No economic model is flawless. Estrella, Mishkin and Trubin show the slope of the US Treasury yield curve can be used to convey estimates of the probability of a recession occurring in the US within the 
next year. ${ }^{25,26}$ The average probability of a recession based on the mean yield curve slope of 1.91 percent over the 25 year period sampled is 2.21 percent. ${ }^{*}$ The probability of a recession occurring in 2007 flashed to a very high 25.59 percent based on the minimal slope of .07 percent posted in 2006. The market indicator suggestive of an imminent recession was then ten times greater than typical and should have raised sufficient concern for directors to adopt more conservative financial strategies. The market provides management and regulatory supervisors with an advance warning that offers time to modify business plans and diminish risk exposure.

Another convenient economic metric illustrative of an adverse shift in the economy is the credit spread between debt securities of the same term but different quality. As shown in Table 1, the average credit spread between medium-quality (i.e., rated A or BBB) corporate bonds and US Treasury bonds over the quarter century depicted is 2.41 percent and ranged from 4.04 percent in 2009 to 1.51 percent in 1997. The spread increases when investors believe a recession is more likely and medium-grade bonds are more probable to be downgraded to speculative status or default and incur losses. Investors sell corporate bonds and buy Treasury bonds in anticipation of a downturn and the actions lead to wider credit spreads. Investors reach for yield in the expansion by purchasing corporate notes and selling Treasuries and the action leads to narrower spreads. The credit spread widened dramatically in 2008 and 2009 prior to the worst period of the US banking bust and had been trending up prior to the onset of the recession.

Recessions within the business cycle are not new events and there are well known metrics to measure the likelihood of economic adversity occurring when management, the board and regulatory supervisors retain experience and remain vigilant. If the board has approved financial policies that increase risk exposure, such as increasing financial leverage, pursuing aggressive growth or entering a new or untested lending market, the consequence can be devastating. The FDIC noted the typical characteristics of the 489 banks failing between 2008 and 2013 included, "heightened concentrations of ADC (real estate acquisition, development and construction) lending, rapid asset growth, reliance on funding sources other than stable core deposits and relatively lower capital-to-assets ratios." ${ }^{27}$ The failing banks did not modify plans or heed warning signs indicative of imminent economic distress. The losses were predictable.

Financial Factors: Rather than present innumerable financial and regulatory ratios common to the banking sector, it is more effective to assess the Risk Index found to have predictive power regarding potential financial and regulatory problems. The financial metric comprises the banking industry's well-known regulatory paradigm known as CAMELS (capital adequacy, asset quality, management, earnings, liquidity and sensitivity). The index evaluates the Tier One Leverage Capital ratio of a bank (i.e., tangible equity divided by total assets), the mean return on assets (ROA) computed over a period of time and risk represented by the sample standard deviation of the return on assets. The index incorporates capital, earnings and risk, and identifies how many standard deviations a bank is from experiencing financial problems during the ensuing year. Statistics are now commonly encountered in the banking industry and more complex regulatory rules.

Risk Index = (Tier One Capital + Mean ROA Regulatory Threshold)/Sample Sigma of ROA

A strong bank will have a high Risk Index (e.g., greater than ten) if it relies on relatively more equity capital to fund assets and earns high profits on a consistent basis that provide the foundation for retaining earnings and creating capital internally. Bankers unable to control risk will experience high year-to-year volatility of earnings, which leads to a high sigma of ROA and a low index. Earnings are inconsistent when management is unable to identify, measure and control credit, interest rate, liquidity and operational risks and pursue inappropriate business strategies. Over 95 percent of banks that failed in 2009 retained a Risk Index less than three in $2008 .^{28}$ There was a high probability the capital for such banks would be less than five percent necessary to be judged well capitalized by Prompt Corrective Action standards then imposed by the FDIC.

Table 3 illustrates the Tier One Leverage Capital ratio, mean $\mathrm{ROA}$ computed over a half-decade between 2013 and 2017, and the sample sigma of ROA derived over the same five-year period for the four largest US banks. These banks comprise 45.3 percent of total banking assets as of 2018. The Risk Index shown for the top four banks can be converted into a probability each bank's capital might decline below the five percent Prompt Corrective Action threshold. ** The largest banks highlighted are also required to hold incremental capital to meet demands applicable to supplementary leverage, a capital surcharge and a countercyclical capital buffer. The Table presents comparable data for an illustrative community bank that failed in 2010 relative to a very low two percent regulatory capital threshold that if violated requires the institution to be liquidated or merged by regulatory authorities.

The four systemically-important US banks have very strong capital ratios and consistently stable profits commensurate with effective risk management as of 2018. With a Risk Index ranging from over 150 to above ten, the probability of the systemically-important banks encountering financial problems is remote and 
consistent with the current strong position of the banking industry. Banks, however, appeared similarly strong prior to other crises chronicled. The weakest of the top four banks (adversely impacted by the 2017 Tax Act rather than operational or credit problems) retains a Risk Index above ten, which is comparable to less than a $1 / 2$ of one percent probability of experiencing incremental regulatory oversight and far above that indicative of failure.

By contrast, the $\$ 13$ billion South Carolina bank closed in 2010 had Tier One Leverage capital of only 7.12 percent as of 2009, an alarming average annual ROA of -1.44 percent lost over the prior five years and an unusually high ROA sigma of 2.84 percent. The Risk Index compared to a two percent threshold was a very low 1.30, which is well below three common to failing banks and a five percent threshold. There was almost a 30 percent chance of problems becoming so severe for the southern bank to require liquidation or merger in 2010. Failure should not have been a surprise to management or the board. The index is able to synthesize a bank's capital, earnings and risk profile regardless of source into one easily measured metric.

The Risk Index will decline for the industry and other common financial metrics, such as problem assets and loan losses, escalate as the US approaches the next challenging eonomic phase of the business cycle when capital ratios decline, earnings become far more erratic and business managers are unable to achieve desired goals from unrealistic business plans. Just as many bankers and regulators fail to monitor deteriorating economic trends illustrated by a flatter yield curve or a increasing credit spread, management of failing banks do not concentrate on the financial metrics indicative of impending problem bank designation. The Offices of the Inspector General for the Department of Treasury and the FDIC evaluated the 2008 failure of Washington Mutual and commented, "Primary areas of concern were the lack of effective internal controls and insufficient commitment of the board to take action to address identified weaknesses." ${ }^{29}$ Ultimately, bank failure reflects tardy bank supervision, poor management and inadequate monitoring and oversight by the board. The losses are preventable.

Managerial Issues: The Cadbury Report published in Britain in 1992 defines corporate governance as the system by which companies are directed and controlled. ${ }^{30}$ The board of directors establishes the direction of an enterprise by approving appropriate policies and business plans, and recruiting, compensating and monitoring executive management and operations to ensure shareholders, among other competing stakeholders, are treated fairly and provided appropriate risk-adjusted returns on capital invested. The board of directors of a regulated bank or bank holding company typically conducts its business by committee. Some committees for US financial institutions, such as audit and enterprise risk, are required by the Securities and Exchange Commission (SEC) and the institution's relevant primary regulator. Other committees, such as credit, finance or information technology, often reflect prior problems encountered by the institution.

As banks create new committees, time demands on directors increase and encourage the board to add new directors. Regulators, consistent with accepted best corporate governance practices, increasingly encourage banks to add additional directors that are not only independent of management but also promote diversity to provide new perspectives by which to monitor management and operations, control risk and create value. Diversity may be narrowly defined, such as by gender or race, or more broadly characterized by features that promote varied business, academic, military and governmental experience.

The managerial model of corporate governance dominated in the United States in the first half of the twentieth century by which the board was mostly comprised of senior executives. Independent directors were identified by, beholden to and supportive of the CEO. Baum succinctly evaluated what precipitated the rise of the monitoring board in the 1970s. ${ }^{31}$

First, the sudden collapse of the major railway company Penn Central in 1970. Second, Eisenberg's influential book 'The Structure of the Corporation' published in 1976. According to Eisenberg, the board's essential function was to monitor the company's management by being independent from it. The reliance on independent directors as a panacea for various corporate governance ills has reached its zenith in the US.

There is mixed support in the banking sector regarding the benefit of independent directors to operate safely and create value as companies shifted strategy from the managerial to the monitoring model. Baum further notes, "The empirical support for staffing boards with independent directors, however, remains surprisingly shaky given the ubiquitous reliance on independent directors. The global financial crisis of 2008 has added further doubts." 32 Erkens et al. studied the performance of almost 300 global financial firms' during the most recent financial crisis and their research did not support the often-stated corporate governance benefit of adding independent directors to a board. ${ }^{32}$ Alonso and Vallelado evaluated a large sample of international commercial banks to test hypotheses related to the dual role of directors (i.e., monitoring and advising). They find, "Larger and not excessively independent boards might prove more efficient in monitoring and advising functions." ${ }^{33}$ These studies suggest independent directors, per se, do not necessarily prevent or preclude financial distress. 
Other governance studies assess the benefit, if any, of board diversity on bank performance. Pathan and Faff conducted a longitudinal study of large US bank holding companies prior to and after the rules of Sarbanes-Oxley were introduced and focused on the composition of boards. They noted, "Although gender diversity improves bank performance in the preSarbanes-Oxley Act (SOX) period (1997-2002), the positive effect of gender diminishes in both the postSOX (2003-2006) and the crisis periods (2007-2011)." ${ }^{34}$ The results are comparable to those expressed by Adams et al. who studied the benefit of gender diversity and found, "Female directors have better attendance records than male directors and more likely to join monitoring committees. These results suggest that gender-diverse boards allocate more effort to monitoring. However, the average effect of gender diversification on firm performance is negative." ${ }^{35}$ Not all studies show efforts to promote gender diversity are misplaced or without merit. Fernandes et al. evaluated the performance of supervisory boards during the recent crisis and found, "Gender and age diversity improved banks' performance during the crisis; hence, diversity matters." ${ }^{36}$ The later results are consistent with an analysis of companies in the non-financial sector by Bernile et al. except during times of financial volatility. ${ }^{37}$ A crisis, however, is precisely the time banks fail and invariably reflects the board's inattention to risk.

The governance literature provides conflicting evidence regarding board structure and performance. If the US is at the inflection point between the last financial crisis and the next period of unwarranted bank failures, governance is critical. In a study of systemicallyimportant US bank holding companies, Handorf focused on board structure and safety and soundness measured by a credit rating. ${ }^{38}$

Holding company boards comprised of more independent directors, to include female directors, achieve better credit ratings. Diversity of experience allows bank holding company boards to make better decisions, formulate superior plans and policies and improve monitoring of operations and executive management. Holding companies with more independent directors on the board err on the side of safety.

Despite the wealth of studies and conflicting conclusions applicable to governance from a sample of divergent studies cited, we have not identified why so banks succumb to economic contraction and incur excessive financial risk. Coktan et al. succinctly addressed this question from a governance perspective, "We find that firms that go bankrupt have smaller, less independent boards and more restrictions on shareholder governance." ${ }^{39}$ Kress further argues, "The directors of the United States' largest financial institutions are too busy to execute their governance roles effectively." ${ }^{40}$ Independent directors must be unburdened by excessive other work to create value and promote a safe and sound institution.

Efforts to refresh the board by instituting mandatory age limits, promote diversity and achieve other laudable corporate governance goals create issues that deserve additional investigation within the banking sector. The typical bank or holding company has three distinct boards between banking crises given an average eight-year tenure of directors and 25 years between crises. The industry is unable to benefit from the well-known error learning model and profit from those directors with experience from prior crises. As earlier noted, failure includes 1) those that are preventable in predictable operations, 2) unavoidable in complex situations and 3) intelligent at the frontier where problems can occur quickly and on a small scale. ${ }^{1}$ Regardless of type of failure, management and the board must learn from its own mistakes and those of others. Yet, the very board turnover believed useful to effective corporate governance by refreshment strategies deprive banks of experience that might prevent mistakes in predictable situations. Nestor links financial institution failure with the characteristics of independent directors, and finds, "The best performing boards were not too young and retained longer average tenure." 41

Over 80 percent of S\&P directors have less than 16 years of tenure on their existing board and many have less than five years of experience. Tversky and Kahneman published the availability heuristic almost 50 years ago. Their award-winning work indicates that recall and memory are important to judgment. ${ }^{42}$ If an event is easier to recall or retrieve from memory, it can be applied more quickly and fully when developing strategy. Relatively new directors have no personal experience of a prior crisis by which to easily retrieve and productively apply to oversight and strategy. Because the crisis prior to that of the Great Recession was a thrift catastrophe and focused on banks judged too-big-too-fail, we more fully assess the board tenure of the three largest savings and loans that failed in the 2008 era. These institutions include IndyMac, Downey and Washington Mutual (WaMu). Other large thrifts and banks would have failed except for ill-timed purchases by bank holding companies. The brief analysis is structured to spur debate of emerging governance practices within the banking system.

Based on 2008 proxy data filed by each savings and loan with the SEC, two of the failing thrifts retained no independent directors with first-hand knowledge of the prior thrift crisis. The two boards had an average tenure of four to six years that deprived the institutions of the availability heuristic that might have allowed some 
experienced directors to incorporate conservatism into planning, monitoring and advising duties. By contrast, the third institution retained five directors with excessively long-term experience that represented almost 40 percent of the board. The later institution had an entrenched board often criticized by governance critics and would have benefitted by board refreshment strategies. The risk manager of the third thrift stated, "It's a crash that can largely be attributed to a failure of culture and governance by the board." ${ }^{43}$

Banks may be able to reduce the likelihood of recruiting a CEO or approving business plans contributing to preventable failure in predictable contractionary economic environments by retaining several directors with long-term banking experience including prior crises. The suggestion requires financial institutions to rethink board refreshment strategies linked to mandatory term and age limits. The relatively few directors retained must maintain good health, mental acuity, commitment and independence. One director's dire warning can be and likely will be ignored by a board dominated by newer directors from diverse fields of expertise. By contrast, two directors of fourteen common in large bank holding companies can forcefully argue against excessive financial risk, compensation plans that encourage undue risk-taking and CEOs focused on short-term results. Failure is acceptable if organizations are able to learn from flawed innovative strategies limited in scope. Failure is unacceptable if preventable in predictable situations.

Banks can learn from history by recruiting and retaining directors at an earlier age and by increasing mandatory age limits for a few experienced directors retaining intellectual abilities, physical well-being, stamina and commitment. Board evaluation is critical to good governance and diversity, and must not be ignored. Byrd et al. articulates a potential problem for boards dominated by long-serving directors, "The relationship between CEO pay and the median tenure of outside directors becomes positive supporting a CEO allegiance hypothesis." ${ }^{44}$ The well-intentioned caveat suggests director independence can be compromised when serving with the same CEO for long periods of time. However, having no long-term independent director experience has its own risk - failure. The proposal advanced in this article is consistent with existent research. Doorga studied the role of independent directors serving on bank boards and indicated, "Longer tenure increases an individual's commitment towards the firm. Highly experienced board members are tougher on management because they understand prior missteps better than newer directors." 45

\section{Conclusion}

US banks have a long history of succumbing to economic contractions aggravated by business strategies focusing on growth, questionable acquisitions, investment in high-yield loans and securities funded by high-cost, non-core sources. Business recessions are not new. The potential adverse consequence of ill-advised business plans on capital, earnings, and liquidity are well known. Congress reacts to a surge of bank liquidations and panics in a predictable manner by holding hearings, enacting a new restrictive law and creating a regulatory agency to ensure the legislative mandate is accomplished. The process repeats every generation in the United States and many other regions of the world.

The governance and crisis literature offer limited guidance. Academic and practitioner studies reach conflicting views. Many, but not all, studies suggest banks with more diverse independent directors adopt more conservative policies and achieve better credit ratings conducive to survival. The directors cannot be too busy and hold senior, full-time positions or serve on many boards simultaneously. More experienced directors, if any are retained as proposed, are likely to have retired from full-time employment and if limit board service to one or two companies should be able to focus on the bank. Several directors, including the lead director, must have banking experience. Most SECregistered banks have such expertise given the expectation that at least one member of the audit committee is a financial expert; most institutions possess far more experts than one director well versed in accounting and finance. The skill set of the board must also include strategic planning, human resource management, marketing and business development, information technology, audit and project management among other personal attributes suggestive of loyalty and care.

Any board retaining a few directors with long experience will likely find these directors exceed common age limits prescribed by "good governance" policies. Each board considering the proposal will need to overcome common "blind spots" that young equals good well known and documented by social psychologists. ${ }^{46}$ Ageism is a very implicit bias in America and other areas of the world.

The proposal will not cure all ills facing the financial sector every generation or so. However, if two experienced, long-term bank directors are able to provide an influential voice against excessive stock repurchase activity, undue dividend payouts, unusually quick growth funded by non-core deposits and borrowed money, expensive acquisitions and unwarranted expansion into high-risk lending and 
investing, the suggestion will prove not only sensible but cost-efficient.

There are many risks to be identified, measured, monitored and controlled within a financial institution. Some risks are well known and others are evolving, such as those applicable to cyber, Cloud computing, cryptocurrency, fintech, vendor management, and social media. Institutions must anticipate the consequence of volatile inflation and interest rates, trade tariffs, a rapidly expanding federal debt and the possibility of a recession. The panoply of risks does require a diverse board and diversity includes a few directors with longterm experience that extends to a prior crisis period.

Repeated legislative efforts to respond to prior crises by introducing a central bank and lender of last resort, providing modest deposit insurance, and requiring more stringent regulatory rules applicable to capital, liquidity, and risk management have not been sufficient despite expectations to the contrary. More recent managerial guidance to include the introduction of the monitoring model, increased reliance on independent directors, and greater attention to diversity and refreshment strategies have produced mixed results. Indeed, Essen et al. found that prior governance recommendations have not allowed banks to prosper or avoid failure during crises, "Good governance prescriptions, such as board independence, incentive compensation and the separation of the CEO and board chair, have on the whole proved harmful to firm performance in times of crisis." ${ }^{77}$ The governance proposal herein advanced pits the availability heuristic suggesting that recall and memory are important to judgement and boards should retain a few long-term experienced directors against the CEO allegiance hypothesis indicating long-term directors can become too close to CEOs and full board turnover is important. The managerial controversy is important to resolve as the US approaches ever closer to the next banking crisis.

\section{Footnotes}

* The probability of a recession using Excel equals: NORMSDIST (-.6045 - .7374 * Yield Curve Slope) where the values were estimated by the authors to obtain the best fit to predicting future recessions. ${ }^{26}$ The slope is the difference in yield between ten-year and three-month US Treasury securities.

* * The Risk Index can be converted into a probability the indicated capital ratio will decline below the regulatory threshold if earnings are symmetrically distributed around the mean rather than normally distributed. For example, an index of ten corresponds to a probability of capital declining below the stated threshold of $1 / 2$ of one percent (e.g., .5[1/\{102\}) while an index of three represents a probability of incurring capital problems of 5.56 percent (e.g., . $5\left[1 /\left\{3^{2}\right\}\right.$ ). It is important to remember that 95 percent of failing banks in the last crisis retained an index of less than three one year prior to failing relative to a five percent capital threshold.

$$
\text { Probability }=.5\left[1 /(\text { Risk Index })^{2}\right]
$$

The analysis is consistent with Tchebysheff's inequality for a symmetrical distribution. The probability multiplies by .5 because of concern with very weak performance below the mean rather than outstanding earnings above the mean. We focus on the left tail of the distribution because that exposure represents the area capital will be judged inadequate relative to the threshold utilized.

Table 1: Annual Bank Failure and Economic and Financial Factors (1992-2017)

\begin{tabular}{|c|c|c|c|}
\hline Factor & Mean & High & Low \\
\hline Banks Failing & 32 & 180 & 0 \\
\hline Real GDP Growth & $2.54 \%$ & $4.69 \%$ & $-2.78 \%$ \\
\hline Unemployment Rate & $5.97 \%$ & $9.60 \%$ & $4.00 \%$ \\
\hline Yield Curve Slope & $1.91 \%$ & $3.58 \%$ & $0.07 \%$ \\
\hline Credit Spread & $2.41 \%$ & $4.04 \%$ & $1.51 \%$ \\
\hline
\end{tabular}

Sources: Federal Deposit Insurance Corporation, Bureau of Economic Analysis (Department of Commerce), Department of Labor and Federal Reserve Bank of St. Louis

Table 2: Correlation Coefficients of Failing Banks and Economic Indicators (1992-2017)

\begin{tabular}{|c|c|c|}
\hline Factor & Real GDP Growth & Unemployment Rate \\
\hline Banks Failing & $-.359^{\star \star}$ & $.827^{\star}$ \\
\hline Lagged Banks Failing (One-year lag) & $-.737^{\star}$ & $.600^{\star}$ \\
\hline
\end{tabular}

Statistical Confidence: *@1\%,**@ @\% 
Table 3: Risk Index and Financial Metrics

\begin{tabular}{|l|c|c|c|c|c|}
\hline \multicolumn{1}{|c|}{ Bank } & Tier 1 Capital & Mean ROA & ROA Sigma & Risk Index & Probability \\
\hline BankAmerica & $9.00 \%$ & $1.19 \%$ & $.03 \%$ & 158.70 & $.002 \%<5 \%$ \\
\hline J P Morgan & $8.71 \%$ & $0.85 \%$ & $.07 \%$ & 62.59 & $.01 \%<5 \%$ \\
\hline Wells Fargo & $8.39 \%$ & $1.32 \%$ & $.12 \%$ & 39.63 & $.03 \%<5 \%$ \\
\hline Citibank & $9.03 \%$ & $0.76 \%$ & $.42 \%$ & 11.49 & $.38 \%<5 \%$ \\
\hline Carolina First & $7.12 \%$ & $-1.44 \%$ & $2.84 \%$ & 1.30 & $29.78 \%<2 \%$ \\
\hline
\end{tabular}

Source: Uniform Bank Performance Reports Compiled by Federal Financial Institutions Council: 2013-2017 for first four banks and 2005-2009 for Carolina First Bank.

\section{References Références Referencias}

1. Edmondson, Amy C. (2011), "Strategies for Learning from Failure," Harvard Business Review (April, Volume 89, Number 4, pp. 48-55).

2. Balachandran, Balasingham and Barry Williams (2018), "Effective Governance, Financial Markets, Financial Institutions \& Crises," Pacific-Basin Finance Journal (Volume 50, September 2018, pp. 1-15)

3. Spencer Stuart (2017),U.S. Board Index (pp. 1-64).

4. Institutional Shareholder Services (2016), 2016-2017 Global Policy Survey, (September 29, pp. 1-23).

5. Subramanian, Guhan (2015), "Corporate Governance 2.0, Harvard Business Review, (March, Volume 92, Number 3, pp. 96-105).

6. Federal Deposit Insurance Corporation (2019), Quarterly Banking Profile: Fourth Quarter 2018, (Volume 13, Number 1, pp. 1-25).

7. Fischoff, B. (1975), "Hindsight Is Not Equal to Foresight: The Effect of Outcome Knowledge on Judgment Under Uncertainty," Journal of Experimental Psychology: Human Perception and Performance (Volume 1, Number 3, pp. 288-299).

8. Rizzi, J. V., (2018), "Relaxing Regulations Could Make Next Crisis Worse," American Banker (March 12).

9. Ensign, Rachael and Lillian Rizzo (2018), "Looser Lending Worries Regulators," Wall Street Journal (May 30, B1).

10. McCoy, Patricia, A. (2018), "Risky Mortgages Primed for Comeback Under Senate Reg Relief Bill," American Banker (March 5, 2018).

11. Dezember, Ryan and Peter Rudegeair (2018), "Investors Turn to 'Drive By' Home Appraisals, Adding Risk," Wall Street Journal (January 22, A1).

12. Whittall, Christopher (2017), "Buyers Snap Up Riskier Leveraged Debt," Wall Street Journal (December 27, B1).

13. Report of the Comptroller of the Currency (1914), Annual Report of the Comptroller of the Currency to the Third Session of the Sixty-third Congress of the United States, (Volume 1, December 7).

14. Santayana, George (1905), The Life of Reason: Reason in Common Sense, (Scribner, p. 284).
15. Hummel, Jeffrey Rogers (2015), "The History of U.S. Recessions and Banking Crises," Booms and Busts, Economic History, the Fed \& Central Banks, (October 22, pp. 1-7).

16. Friedman, Milton and Anna Swartz (1963), A Monetary History of the United States: 1867-1960, (Princeton University Press, pp. 1-860).

17. Bernanke, Ben (1983), Non-Monetary Effects of the Financial Crisis in the Propagation of the Great Depression," The American Economic Review, (Volume 73, No. 3, pp. 257-276).

18. Boyd, John and Mark Gertler (1994), "The Role of Large Banks in the Recent U.S. Banking Crisis," Federal Reserve Bank of Minneapolis Quarterly Review, (Winter, Volume 18, Number 1, pp. 2-21).

19. Calomiris, Charles (2010), "Banking Crises Yesterday and Today," Financial History Review, (Volume 17, Issue 1, pp. 3-12).

20. Parsons, Richard (2012), "Banks Should Reject More Board Candidates," American Banker (October 19).

21. Kindleberger, Charles (1978), Manias, Panics and Crashes: A History of Financial Crises, (Basic Books, New York, pp. 1-318).

22. Diamond, Douglas and Philip Dybvig (1983), "Bank Runs, Deposit Insurance and Liquidity," Journal of Political Economy, (Volume 91, Issue 3, pp. 401-419).

23. Knox, J. (1903), A History of Banking in the United States, (Bradford Rhodes, New York, p. 194).

24. Van Horne, James (1965), "Interest Rate Risk and the Term Structure of Interest Rates," Journal of Political Economy, (Volume 73, pp. 344-351).

25. Estrella, Arturo and Frederic Mishkin (1996), "Predicting US Recessions: Financial Variables as Leading Indicators," Federal Reserve Bank of New YorkCurrent Issues in Economics, (Volume 2, Number 7, pp. 1-6).

26. Estrella, Arturo and Mary Trubin (2006), "The Yield Curve as a Leading Indicator: Some Practical Issues, " Federal Reserve Bank of New York Current Issues in Economics and Finance (Volume 12, Number 5, pp. 1-8).

27. Federal Deposit Insurance Corporation (2017), Crisis and Response: An FDIC History, 2008-2013. 
28. Handorf, William (2009), "The Panic of 2008: Bank Failure and Commercial Real Estate," Real Estate Review, (Volume 38, Number 4, pp. 27-37).

29. Offices of the Inspector General, Department of the Treasury and Federal Deposit Insurance Corporation (2010), Evaluation of Federal Regulatory Oversight of Washington Mutual Bank, (April, Report No. EVAL-10-002, pp. 1-92).

30. Cadbury, Adrian, committee chair, Committee on the Financial Aspects of Corporate Governance in the UK (1992), "The Financial Aspects of Corporate Governance."

31. Baum, Harald (2016), "The Rise of the Independent Director: A Historical and Comparative Perspective," Max Planck Private Law Research Paper (16/20).

32. Erkins, David, Minyi Hung and Pedro Matos (2012), "Corporate Governance in the 2007-2008 Financial Crisis: Evidence from Financial Institutions Worldwide," Journal of Corporate Finance, (Volume 18, Issue 2, pp. 389-411).

33. Alonso, Pablo de Andres and Eleuterio Vallelado (2008), "Corporate Governance in Banking: The Role of the Board of Directors," Journal of Banking \& Finance, (Volume 32, Issue 12, pp. 2570-2580).

34. Pathan, Shams and Robert Fall (2013), "Does Board Structure in Banks Really Affect their Performance?," Journal of Banking \& Finance, (Volume 37, Issue 5, pp. 1573-1589).

35. Adams, Renee, and Hamid Mehran (2012), "Bank Board Structure and Performance," Journal of Financial Intermediation, (Volume 21, Issue 2, pp. 243-267).

36. Fernandes, Catarina, Jorge Farinha, Francisco Vitorino and Cesario Mateus (2017), "Supervisory Boards, Financial Crises and Bank Performance: Do Board Characteristics Matter?," Journal of Banking Regulation, (Volume 18, Issue 4, pp. 310-317).

37. Bernile, Gennaro, Vineet Bhagwat, and Scott Yonker (2018), "Board Diversity, Firm Risk, and Corporate Policies," Journal of Financial Economics, (Volume 127, Issue 3, pp. 588-612).

38. Handorf, William (2018), "Value Creation, Risk Management and US Bank Holding Company Governance," Global Journal of Management and Business Research: Finance, (Volume 18, Issue 3, pp. 1-15).

39. Goktan, Sinan, Robert Kieschnick and Rabih Moussawi (2018), "Corporate Governance and Firm Survival," The Financial Review, (Volume 53, Issue 2, pp. 209-253).

40. Kress, Jeremy (2017), "Board to Death: How Busy Directors Could Cause the Next Financial Crisis," Ross School of Business Working Paper No. 1370, (June, pp. 1-42).
41. Ladipo, David and Stilpon Nestor (2009), Bank Boards and the Financial Crisis, (Nestor Advisors Ltd. May).

42. Tversky, Amos and Daniel Kahneman (1973), "Availability: A Heuristic for Judging Frequency and Probability," Cognitive Psychology, (Volume 5, Issue 2, pp. 207-232).

43. "Failed Board, Failed Bank: First in a Series on Governance (2018), The Boost/Credit Union Today, (July 23).

44. Byrd, John, Elizabeth Cooperman and Glenn Wolfe (2010), "Director Tenure and the Composition of Bank CEOs," Managerial Finance, (Volume 36, Issue 2, pp. 86-102).

45. Doorga, Renoe (2014), "Independent Directors on Bank Boards: What is Their Added Value?," (Tilburg University, pp. 1-110).

46. Banaji, Mahzarin and Anthony Greenwald (2016), Blind Spot, Bantam Books, New York.,"

47. Essen, M V., P-J Engelen and M. Carney (2013), "Does 'Good' Corporate Governance, Help in a Crisis? The Impact of Country and Firm-level Governance Mechanisms in the European Financial Crisis," Corporate Governance: An International Review, (Volume 21, Issue 3, pp. 201-224. 